\title{
Tobacco corporate social responsibility and fairy godmothers: the Framework Convention on Tobacco Control slays a modern myth
}

\author{
Gerard Hastings, ${ }^{1}$ Jonathan Liberman ${ }^{2}$
}

This will not come as a great surprise to many readers, but it turns out that multinational tobacco companies are not generous, kind hearted or benevolent, and that any similarity they bear to boy scouts or fairy godmothers is dangerously misleading. The Framework Convention on Tobacco Control (FCTC) Conference of the Parties (COP), meeting last November in Durban, reminded us of these truths. It recognised that tobacco company corporate social responsibility (CSR), whether in the form of donations to charity, support for good causes or lavishly funded campaigns trumpeting their own virtuous behaviour, is in fact a self-seeking marketing tool designed to win friends and influence people. It is as much part of ensnaring new generations of tobacco users as are cowboys and camels.

This paper explains how CSR forms part of the tobacco industry's wider marketing strategy and, reassuringly, that the FCTC sees CSR for what it is.

\section{BUSINESS AS USUAL}

Tobacco control has long been sceptical about tobacco industry good deeds. The obvious disconnect between ethical behaviour and selling an addictive, lethal product underpins what Chapman described as a "wholesale cynicism and disgust in health and medical circles". Similarly, albeit it in more measured tones, Hirschhorn warns against "the uncritical acceptance of the tobacco industry's mantle of social responsibility", ${ }^{2}$ pointing out that the already much sinned-against smoker is a key target of its disingenuous charm offences.

\footnotetext{
${ }^{1}$ Centre for Tobacco Control Research, University of Stirling and the Open University, Stirling, UK:

${ }^{2}$ Framework Convention Alliance and VicHealth Centre for Tobacco Control, The Cancer Council Victoria, Carlton, Victoria, Australia

Correspondence to: Gerard Hastings, Centre for

Tobacco Control Research, University of Stirling and the Open University, Stirling, UK; gerard.hastings@stir.ac.uk
}

More recently commentators have also emphasised that tobacco industry CSR is not just an oxymoron, but also a powerful marketing tool. Yang and Malone, ${ }^{3}$ for example, point out that the Philip Morris (PM) "societal alignment" initiative was more about shifting social norms to enable "business as usual" than improving business practices. It is also apparent that social responsibility initiatives have been used to exploit divisions in the tobacco control community ${ }^{4}$ especially in the areas of harm reduction ${ }^{5}$ and collaboration. More recently still, Tesler and Malone show how one tobacco company has used "philanthropy strategically to improve company image, influence policymakers, and influence public health policies". 6

It is apparent, then, that the key word in the phrase "corporate social responsibility" is "corporate" because the aim is to benefit the standing and success of the corporate sponsor. However good the cause it is vital to identify the inevitable quid pro quo. In the case of the tobacco industry, the payback for CSR comes in respectability, legitimacy and the right to continue doing - and growing - its business. In other words, the cost is more tobacco users, more addiction and more premature death.

CSR is a subset of stakeholder marketing, which also takes in cause-related marketing (linking your company or product to a good cause) and corporate affairs (networking with stakeholders). These are the activities corporations-including multinational tobacco companies - engage in to manage their relationship with wider society. An Economist special report ${ }^{7}$ divides CSR into three layers: corporate philanthropy (giving to good causes of one sort or another); risk management (generosity after some reputation-damaging event such as a lawsuit for smuggling or causing harm to consumers) and value creation (the strategic use of good behaviour to build competitive advantage).
The same report goes on to specify the benefits of CSR, which include enhanced reputation, better staff recruitment and the avoidance of "heavy handed Government regulation". ' Similarly Noreena Hertz confirms that CSR's close cousin cause-related marketing "enhances corporate image, builds brands, generates PR and increases sales". ${ }^{8}$ The benefits then are considerable, but crucially they accrue to the corporation not society; the shareholder not the citizen. In a more truthful world, CSR would stand for "corporate self-regard".

The deployment of CSR is simply a recognition by business that it operates in a social context comprising political, regulatory, economic, technological and competitive forces and that there is much to be gained from making this environment as supportive as possible." "Corporate social responsiveness", therefore, "refers to the capacity of a corporation to respond to social pressure" ${ }^{10}$ not its capacity to do good.

CSR is then a core part of the business process, which like all the other components, is deliberately designed to benefit the company and maximise shareholder value. Niall Fitzerald, former chief executive officer (CEO) of Unilever, leaves no doubt about this: "Corporate social responsibility is a hard-edged business decision". [We do it] "not because it is a nice thing to do or because people are forcing us to do it..." [but] "because it is good for our business". ${ }^{11}$ This fits with the fiduciary responsibility of the corporation, which gives paramount importance to the shareholder. When Milton Friedman famously maintained that "the social responsibility of business is to increase its profits" he was not making a debating point, he was stating a truism.

\section{THE NATIONAL CANCER INSTITUTE MONOGRAPH}

It is easy to forget these hard-edged realities when considering individual examples of CSR. Supporting literacy programmes in Brazil (PM), biodiversity in Bangladesh (British-American Tobacco (BAT)) and recycling in Burkina Faso (Imperial Tobacco) all seem to be selfevidently desirable activities; how could anyone object to them?

The latest National Cancer Institute (NCI) monograph (fig 1), however, shows how tobacco companies use these activities, just as they use other marketing activities to promote tobacco. At the centre of the figure is mass media advertising, the most obvious of tobacco promotion tools. This is nested in a range of other communications activities such as public relations (PR) and sports 
sponsorship, and the core consumer marketing functions of product development, pricing and distribution. These in turn mesh with stakeholder marketing and CSR - whether tobacco related such as youth prevention work, or more general as with literacy or recycling. The only difference between the conventional marketing at the centre of fig 1 and CSR is that the former targets potential customers, while the latter is more concerned with stakeholders and potential regulators.

Furthermore, consumer and stakeholder marketing combine to form a synergistic and carefully honed strategy whose core purpose is, again, to promote tobacco and enhance the success and profitability of the tobacco company.

The impact of the three inner layers of tobacco promotion depicted in fig 1 is well understood. The impact of stakeholder marketing and CSR has been less well researched and, until recently, largely overlooked by tobacco control. ${ }^{6}$

\section{THE FCTC RESPONSE}

Fortunately the FCTC is robust enough to take on CSR. Its definitions are admirably broad: "Tobacco advertising and promotion" it states comprises "any form of commercial communication, recommendation or action with the aim, effect or likely effect of promoting a tobacco product or tobacco use either directly or indirectly" and "tobacco sponsorship" is defined as "any form of contribution to any event, activity or individual with the aim, effect or likely effect of promoting a tobacco product or tobacco use either directly or indirectly" (Article 1).

\section{So the net is wide enough}

Under Article 13 of the FCTC, the 161 Parties to the Convention have agreed to put in place a "comprehensive ban of all tobacco advertising, promotion and sponsorship" up to the full limits of their constitutions.

So the net is strong enough.

In November, the COP (the governing body of the FCTC, constituted by its 161 Parties) adopted guidelines for implementation of Article 13. These tackle CSR head on, recognising its true purpose and the harm it does to public health. Specifically they conclude that contributions by tobacco companies to other entities for "socially responsible causes" are in fact a form of sponsorship; and that the publicising of "socially responsible" business practices, such as good employee-employer relations or environmental stewardship, is

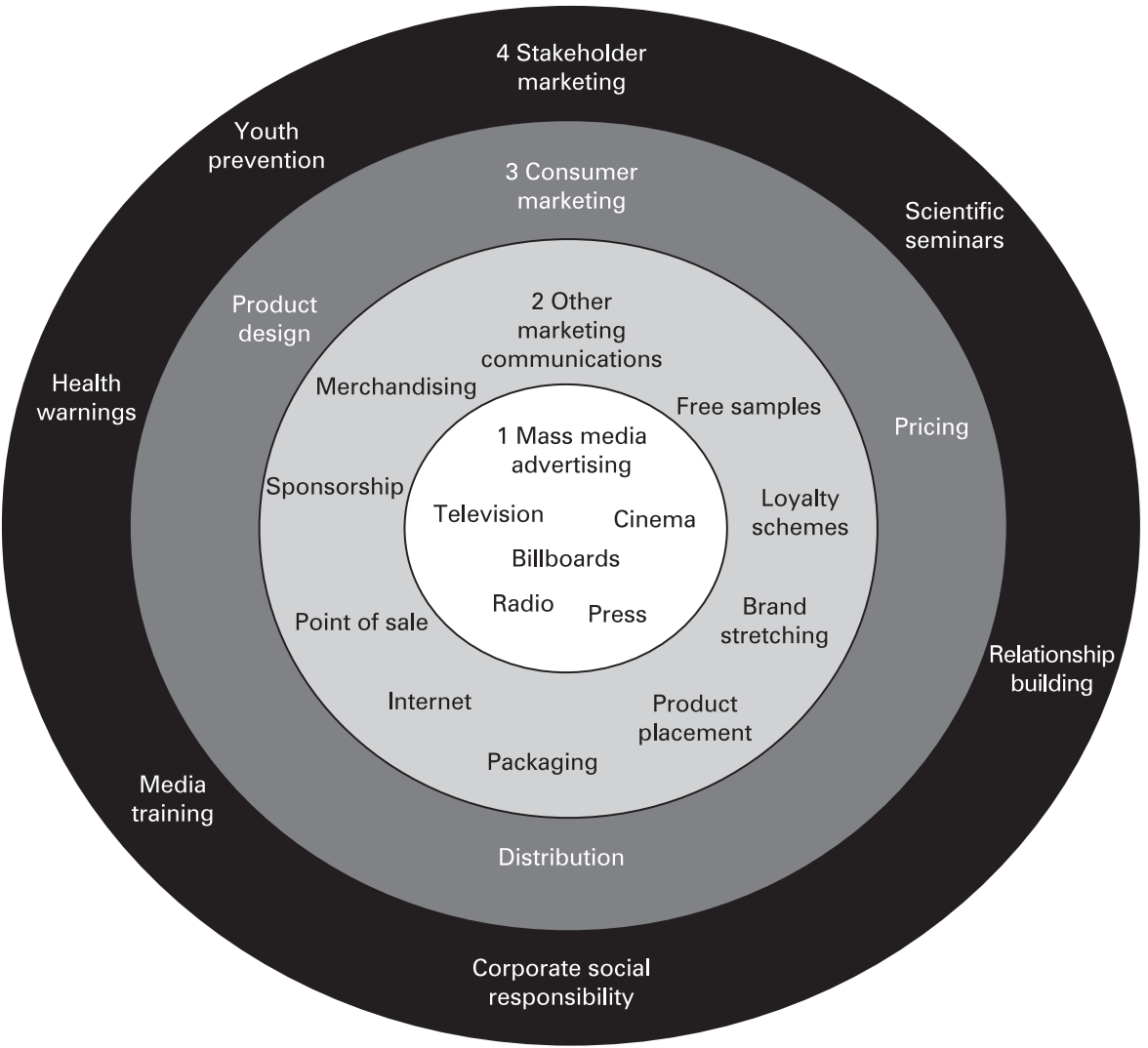

Source: National Cancer Institute ${ }^{12}$

Figure 1 The role of corporate social responsibility (CSR) in tobacco promotion. Source: National Cancer Institute. $^{12}$ just another variation on tobacco promotion. They therefore recommend that both be banned.

So, most importantly of all, there is a willingness and clear commitment to use the net.

\section{CONCLUSION}

Tobacco companies exist to enrich their shareholders by selling tobacco. Everything they do is focused on this goal; indeed, as corporations they are legally obliged to make this their priority. So when they support good causes or fund youth prevention campaigns they do so not because they care, but because it helps their business. Tobacco industry corporate social responsibility is a confidence trick in the light and mild tradition, designed to hide malevolent purpose behind an attractive label.

Thanks to the FCTC and the excellent work undertaken in Durban, this faux altruism should now become a thing of the past.

Funding: GH receives funding from Cancer Research UK.

Competing interests: None declared.

Tobacco Control 2009;18:73-74.

doi:10.1136/tc.2008.029264

\section{REFERENCES}

1. Chapman S. Corporate schmoozing interruptus: denormalising tobacco industry. Tob Control 2004;13:445-7.

2. Hirschhorn N. Corporate social responsibility and the tobacco industry: hope or hype? Tob Control 2004;13:447-53.

3. Yang JS, Malone RE. "Working to shape what society's expectations of us should be": Philip Morris' societal alignment strategy. Tob Control 2008;17:391-8.

4. McDaniel P, Smith E, Malone RE. Philip Morris's Project Sunrise: weakening tobacco control by working with it. Tob Control 2006;15:215-23.

5. Hastings G, Angus K. Forever cool: the influence of smoking imagery on young people. London, UK: British Medical Association Board of Science, 2008.

6. Tesler LE, Malone RE. Corporate philanthropy, lobbying, and public health policy. Am J Pub Health 2008;98:2123-33.

7. Franklin D. Just good business. The Economist, 17 January 2008. http://www.economist.com/ specialreports/displayStory.cfm?story id $=10491077$ (accessed 1 July 2008).

8. Hertz N. The silent takeover: global capitalism and the death of democracy. New York, USA: The Free Press, 2001: 181.

9. Jobber D. Principles and practice of marketing, 4th edn. Maidenhead, UK: McGraw-Hill International, 2004

10. Frederick WC. Year 1978 walking the talk: from social responsibility to social responsiveness. In: Corporation, be good! The story of corporate social responsibility. Indianapolis, Indiana, USA: Dog Ear Publishing, 2006:40.

11. Elliott L. Cleaning agent. Interview: Niall FitzGerald, Co-Chairman and Chief Executive, Unilever. The Guardian 5 July 2003:32.

12. National Cancer Institute (NCI). Davis RM, Gilpin EA, Loken B, Viswanath K \& Wakefield MA, eds. The role of the media in promoting and reducing tobacco use. NCl Tobacco Control Monograph Series No. 19 Bethesda, Maryland, USA: US Department of Health and Human Services, National Institutes of Health, National Cancer Institute, 2008. 